\title{
Detection and characteristics of sulfamethoxazole-resistant bacteria in constructed wetlands treating sulfamethoxazole-rich wastewater
}

\author{
ALEKSANDRa ZIEMBIŃSKa-BUCZYŃSKA*, KAROLINA WYSZYŃSKA, KORNELIUSZ MiKSCH \\ The Silesian University of Technology, Environmental Biotechnology Department, Gliwice, Poland
}

\begin{abstract}
Constructed wetlands $(\mathrm{CW})$ are one of the biological wastewater treatment systems that reflect the natural processes occurring in swamps. Constructed wetlands use microbiological and physico-chemical processes as well as plant metabolism in order to purify wastewater. In such treatment systems, the role of microorganisms is crucial. In this experiment, synthetic communal wastewater containing sulfamethoxazole (SMX; chemotherapeutic) at a concentration of $5 \mathrm{mg} / \mathrm{l}$ was applied in the $\mathrm{CW}$ systems, both unplanted and planted with Phalaris arundinacea, also known as reed canary grass. Fourteen Gram-positive SMX-resistant bacteria strains were isolated from the $\mathrm{CW}$ column fillings and the plant rhizosphere. All of these were identified as representatives of Bacillus sp. based on 16S rRNA sequencing. Despite this molecular identification, the isolates differed significantly in their biochemical features. All 14 isolates presented resistance toward sulfamethoxazole and all 14 strains possessed a sul1 gene, while only 4 gave positive results in sul2 and 3 in sul3 PCR tests. None of the isolated strains possessed all three sul genes. A PCR-DGGE based analysis of the presence of SMX-resistant bacteria in the $\mathrm{CW}$ community was undertaken. It was found that none of the isolates represented the dominant genotype in the bacterial community.
\end{abstract}

Key words: biochemical characterization of SMX-resistant bacteria, lab-scale constructed wetlands, PCR-DGGE, sulfamethoxazole-resistant bacteria

\section{Introduction}

The problem of antibiotic resistance spreading in the environment is recognized worldwide. Antibiotics are considered to be responsible for antibiotic resistance transfer in the environment (Nŏlvak et al., 2013; Martínez, 2009). Among a large number of antibiotics and chemotherapeutics used in everyday treatment of bacterial diseases, sulfonamides, such as sulfamethoxazole (SMX), have been widely used since 1935 (Perreten and Boerlin, 2003). The mechanism of sulfonamide-resistance is based on the presence of three types of sulfonamide resistance genes: sul1, sul2 and sul3. The resistance to sulfonamides can be transferred via integrons, transposons or plasmids (Hammerum et al., 2006). In the case of SMX-resistance, recognition of and re- search on sul genes are the main topics of interest. SMX is present in the environment as are sul genes, because their DNA is relatively resistant to environmental influence. Moreover, such DNA can be taken up directly by bacteria. SMX and sul genes are also present in wastewater treatment plants (WWTPs) and in the technological ecosystems, inside which antibiotic resistance transfer has been well recognized (Łuczkiewicz et al., 2013; Suzuki et al., 2013; Suzuki et al., 2015; Xu et al., 2015).

One WWTP system that is becoming an interesting research topic is constructed wetlands (CW). These systems reflect the biological processes occurring in the natural environment of swamps. The treatment processes are based on biological degradation performed by

\footnotetext{
* Corresponding author: The Silesian University of Technology, Environmental Biotechnology Department, Akademicka 2, 44-100 Gliwice, Poland; e-mail: aleksandra.ziembinska@polsl.pl
} 
microorganisms and further supported by the plants' ability to metabolize/absorb certain chemicals. The presence of plants hastens the redox processes which are linked with sorption, sedimentation and assimilation, and thus enables wastewater treatment (Vymazal, 2005). The plant rhizosphere is also a place with an abundance of bacteria performing biochemical reactions for wastewater treatment.

Wastewater treatment within a constructed wetland system is based on the performance of a complex microbial community. It could be suspected that antibioticresistant bacteria could form a large part of this biocoenosis. For the analysis of such a community structure, PCR-DGGE (Polymerase Chain Reaction - Denaturing Gradient Gel Electrophoresis) is a useful method (Muyzer et al., 1993). This is based on an electrophoretic separation of PCR amplicons according to their melting temperature. As a result, a DNA fingerprint representing the complexity of the bacterial community is obtained. When PCR-DGGE separation of the total community is performed, it is possible, in addition to the DNA bands representing PCR-products obtained from the bacterial isolates, to identify with a high degree of certainty those microorganisms which are the dominant genotypes in the community.

Because the presence of SMX in the treated wastewater can be a causative factor of SMX-resistance in the bacterial cells, the aim of this research was both to isolate SMX-resistant bacteria from lab-scale constructed wetland column fillings and the plant rhizosphere and to obtain their biochemical and genetic characterization. To check if SMX-resistant bacteria are the dominant genotypes in lab-scale constructed wetland systems, the presence of SMX-resistant genotypes in the genotypic structure of total bacterial community was assessed using the PCR-DGGE. This research is the first step to determining the location and potential role of SMX-resistant bacteria in a CW system treating SMX-rich wastewater.

\section{Materials and methods}

\section{Technological system characteristics and the sampling procedure}

Samples for sulfamethoxazole-resistant bacteria isolation were collected from a lab-scale vertical flow constructed wetland system (CW) situated at the Center of Biotechnology, the Silesian University of Technology,
Table 1. Wastewater feeding the constructed wetland system ( $5 \mathrm{mg} / \mathrm{l}$ of sulfamethoxazole was added to experimental columns)

\begin{tabular}{|c|c|c|}
\hline \multicolumn{3}{|c|}{ Synthetic wastewater composition } \\
\hline compound & \multicolumn{2}{|c|}{ concentration [mg/l] } \\
\hline Urea & \multicolumn{2}{|c|}{208.76} \\
\hline $\mathrm{NH}_{4} \mathrm{Cl}$ & \multicolumn{2}{|c|}{0.62} \\
\hline Sodium acetate & \multicolumn{2}{|c|}{510.4} \\
\hline Peptone & \multicolumn{2}{|c|}{40} \\
\hline $\mathrm{KH}_{2} \mathrm{PO}_{4}$ & \multicolumn{2}{|c|}{41.37} \\
\hline Yeast extract & \multicolumn{2}{|c|}{264} \\
\hline Milk & \multicolumn{2}{|c|}{118} \\
\hline \multicolumn{3}{|c|}{ Trace metals } \\
\hline salt & $\begin{array}{c}\text { salt concentration } \\
{[\mathrm{mg} / \mathrm{l}]}\end{array}$ & $\begin{array}{c}\text { ion concentration } \\
{[\mathrm{mg} / \mathrm{l}]}\end{array}$ \\
\hline $\mathrm{KCr}\left(\mathrm{SO}_{4}\right)_{2} \cdot 12 \mathrm{H}_{2} \mathrm{O}$ & 0.96 & 0.1 \\
\hline $\mathrm{CuSO}_{4} \cdot 5 \mathrm{H}_{2} \mathrm{O}$ & 0.781 & 0.2 \\
\hline $\mathrm{MnSO}_{4} \cdot \mathrm{H}_{2} \mathrm{O}$ & 0.108 & 0.035 \\
\hline $\mathrm{NiSO}_{4} \cdot 7 \mathrm{H}_{2} \mathrm{O}$ & 0.359 & 0.075 \\
\hline $\mathrm{PbCl}_{2}$ & 0.1 & 0.075 \\
\hline $\mathrm{ZnCl}_{2}$ & 0.208 & 0.1 \\
\hline $\mathrm{MgSO}_{4} \cdot 7 \mathrm{H}_{2} \mathrm{O}$ & 4.408 & 0.43 \\
\hline
\end{tabular}

Gliwice, Poland. The system consists of steel columns filled with a mixture of sand and gravel. The system was used to treat communal wastewater (Table 1) with the addition of sulfamethoxazole at the concentration of $5 \mathrm{mg} / \mathrm{l}$. The system was fed 4 times per day with 0.351 of wastewater. The samples were collected from the experimental installation comprising 4 columns, of which two were experimental columns fed with a synthetic medium containing sulfamethoxazole. The two other columns were the controls without SMX addition. In both sets, the experimental and the control, one column was planted with Phalaris arundinacea. Figure 1 presents the scheme of the experimental system. Samples were collected from the depth of $10 \mathrm{~cm}$ from the filling of the columns, and in the case of the planted columns the plant rhizosphere was also collected.

\section{Isolation of sulfamethoxazole-resistant bacterial strains}

The samples collected (in triplicate) from the $\mathrm{CW}$ system were suspended in $1 \times$ PBS (phosphate buffered saline), vortexed for $3 \mathrm{~min}$ and left for sedimentation. The samples were diluted in $1 \times$ PBS to final $10^{-3}$ con- 


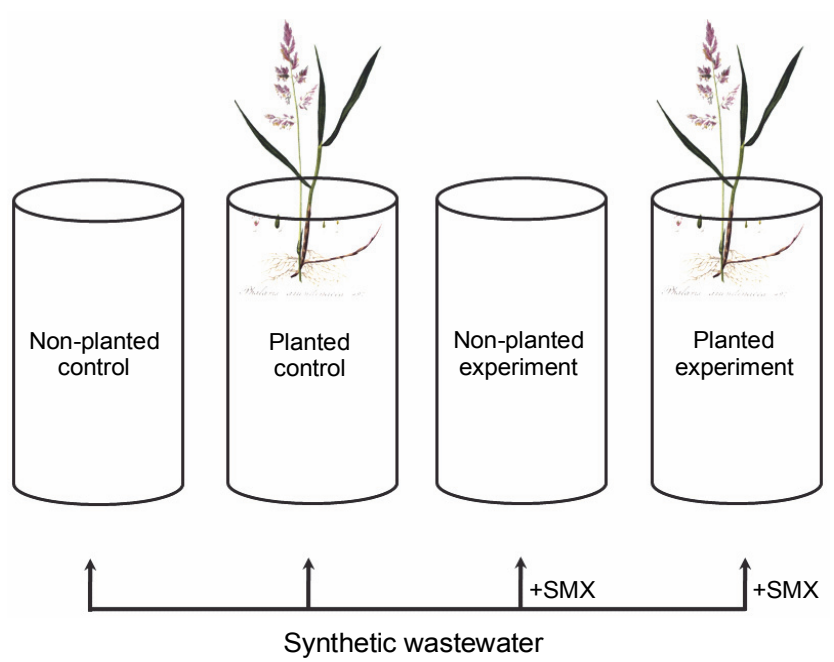

Fig. 1. Scheme of the experimental system

centration. Mueller-Hinton agar (BTL, Łódź, Poland) with the addition of $5 \mathrm{mg} / \mathrm{l} \mathrm{SMX}$ was used for isolating SMX-resistant bacteria. The agar plates were incubated for $24 \mathrm{~h}$ at $37^{\circ} \mathrm{C}$. Well separated single colonies were inoculated on broth agar plates (BTL, Łodź, Poland) and after $24 \mathrm{~h}$ incubation at $37^{\circ} \mathrm{C}$ these were used for further laboratory procedures.

\section{Microscopic and biochemical characterization of bacterial strains}

The isolated SMX-resistant bacterial strains underwent Gram staining and biochemical characterization with a series of biochemical tests. The strains were tested: for the production of $\beta$-galactosidase, arginine dihydrolase, lysine decarboxylase, ornithine decarboxylase, urease, gelatinase, tryptophan deaminase, oxidase, catalase, $\mathrm{H}_{2} \mathrm{~S}$, indole, and acetoin; and for fermentationoxidation of glucose, mannitol, inositol, sorbitol, L-rhamnose, D-saccharose, D-melibiose, amygdaline, L-arabinose and citrate utilization (Biomerieux, France). The tests were performed according to the manufacturer's instructions. Also, a test for hemolysis with Columbia agar containing 5\% sheep blood (Biomerieux, France) was performed according to the manufacturer's instructions.

\section{Molecular identification of bacterial strains}

Total bacterial DNA from SMX-resistant strains was isolated with a Genomic Mini Kit (A\&A Biotechnology, Poland) according to the manufacturer's instructions. Molecular identification was performed by 16S rRNA gene sequencing. For this procedure, $\mathrm{PCR}$ amplification was performed with $8 \mathrm{~F}$ ( $5^{\prime}$-GTGCTGCAGAGAGTTT GA TCCTGCTCAG-3') and 1401R (5'-CGGTGTGTACAAG GCCC-3') primers (Genomed).

The PCR mixture consisted of: $1.5 \mathrm{U}$ GoFlexi Taq Polymerase with $1 \times$ buffer (Promega), $2 \mathrm{mM} \mathrm{MgCl}$, $5 \mathrm{pM} / \mu \mathrm{l}$ of each primer, $20 \mathrm{pM} / \mu \mathrm{l} \mathrm{dNTPs}$ and 0.15 $0.2 \mu \mathrm{g} / \mu \mathrm{l}$ of isolated DNA. The mixture was filled to $30 \mu \mathrm{l}$ with MiliQ water. The amplification steps were as follows: predenaturation $5 \mathrm{~min} / 95^{\circ} \mathrm{C}, 30$ cycles of denaturation $45 \mathrm{sec} / 95^{\circ} \mathrm{C}$, annealing $45 \mathrm{sec} / 54^{\circ} \mathrm{C}$, elongation $45 \mathrm{sec} / 72^{\circ} \mathrm{C}$, and at the end final elongation $5 \mathrm{~min} / 72^{\circ} \mathrm{C}$.

The PCR products were purified with a Clean Up Kit (A\&A Biotechnology) and sequenced with an ABI Prism sequencer using a BigDye Terminator Kit v3.1 (Applied Biosystems Life Technologies). The identification was performed with the BLAST tool and compared with the GenBank NCBI database.

\section{Test for the presence of sul genes responsible for SMX-resistance}

All the SMX-resistant strains were tested for the presence of sulfonamide resistance genes (sul1, sul2 and sul3) using PCR amplification. The PCR mixture was as described for molecular identification. The primers used in this study and the PCR amplification were as previously described in Perreten and Boerlin (2003). The PCR product was analyzed with $1 \%$ agarose gel electrophoresis in $1 \times$ TBE buffer for $30 \mathrm{~min}$ at $100 \mathrm{~V}$. The gel was stained with ethidium bromide (Promega) and visualized under UV light and photographed with a GelDoc System (BioRad).

\section{The presence of SMX-resistant bacterial genotypes in CW communities with PCR-DGGE}

Total bacterial DNA from resistant strains obtained from $\mathrm{CW}$ columns was isolated with a mechanical method as previously described (Ziembińska-Buczyńska et al., 2015). The $180 \mathrm{bp}$ amplicons of partial 16S rRNA coding genes were generated with the PCR method according to the previous procedure (Muyzer et al., 1993).

The PCR amplicons were separated electrophoretically in a polyacrylamide (acrylamide-bisacrylamide $37.5: 1$, Sigma Aldrich) gel with 30-60\% gradient of urea and formamide as denaturants. The electrophoresis was performed for $6 \mathrm{~h}$ at $100 \mathrm{~V}$ under a constant temperature of $60^{\circ} \mathrm{C}$ with $1 \times \mathrm{TAE}$ buffer. The gel was stained with SYBR Gold (1:10000, Invitrogen), visualized under UV light and photographed with a GelDoc System (Biorad). 


\section{Results}

In the experiment, 14 SMX-resistant strains (KK1KK14, well separated from other colonies on the agar plates) were isolated from the constructed wetland columns treating synthetic wastewater which contained sulfamethoxazole at the concentration of $5 \mathrm{mg} / 1$. All isolated strains were Gram-positive. None of the isolated strains produced $\beta$-galactosidase, lysine decarboxylase, $\mathrm{H}_{2} \mathrm{~S}$, urease, tryptophan deaminase or indole. None of the strains fermented mannitol, inositol, sorbitol, L-rhamnose, or D-melibiose. All of the SMX-resistant strains were oxidase-negative. In the case of other biochemical tests, the isolated strains differed. Strains KK1 to KK5, KK8, KK10 and KK12 to KK14 produced arginine dihydrolase. Strain KK3 was capable of producing ornithine decarboxylase. Citrate utilization was performed by strains KK3 to KK7. Strains KK1 to KK7 produced acetoin, while KK2 to KK7 and KK10 to KK14 produced gelatinase. Only KK2 strain was able to ferment glucose, and strains KK2 and KK4 were able to ferment D-saccharose. Amygdaline was fermented by strains KK1 to KK4, KK7, KK9, KK11-KK13. All but two strains (KK5 and KK6) were able to ferment L-arabinose. Seven out of the 14 strains were hemolytic (KK: 1, $4,5,7,12,13,14)$ and 11 out of the 14 produced catalase (KK: 1, 2, 4, 5, 6, 7, 9, 11, 12, 13, 14). The results of biochemical tests performed on the bacteria are presented in Table 2.

On the basis of $16 \mathrm{~S}$ rRNA gene sequencing, all the SMX-strains were identified as belonging to Bacillus species. The most problematic was the sequence analysis of the KK2 strain. The sequencing was repeated several times, but identification to $B$. cereus was possible only with $81 \%$ certainty. Strains KK 2, 3, 4, 5, 7, 9, 10, 11, 13, 14 were identified as $B$. cereus. The KK1 strain was identified as either B. cereus or B. thuringensis, with the same degree of probability. Strain KK6 was identified as $B$. subtilis or B. methylotrophicus, with the same degree of probability, while KK11 was identified as $B$. amyloliquefaciens (Table 3 ).

To characterize the molecular mechanism of SMXresistance of all strains isolated in the study (KK1KK14), the analysis of sul1, sul2 and sul3 genes, which are known to be responsible for SMX-resistance, was performed with the PCR method. All 14 isolates possessed the sul1 gene, only four (KK1, KK11-KK13) posses- sed the sul2 gene and three isolates (KK3-KK5) had the sul3 gene. None of the tested bacterial strains possessed all three sul gene types (Table 4).

To assess the presence of the SMX-resistant bacteria genotypes in the total bacterial community of the labscale CW system, PCR-DGGE analysis was performed. The DGGE fingerprints obtained for strains KK1-KK4 and the lab-scale $\mathrm{CW}$ total community both with and without SMX-addition are presented in Figure 2. The SMX-resistant strains possess several 16S rRNA gene copies visible as multiple bands in their fingerprints. The $\mathrm{CW}$ community fingerprints are more complex; nonetheless, all DNA bands in the visualized fingerprints are poorly visible on a relatively bright background.

\section{Discussion}

One of the wastewater treatment plant systems that has become an interesting research topic for both technological and microbial research is constructed wetlands (CW). These systems reflect biological processes that occur in the natural environment of swamps. Wastewater treatment is based on biological processes performed mainly by the bacterial community, further supported by the capabilities of plant metabolisms. The bacterial community present in constructed wetlands is still recognized as a "black box" and this varies in different systems. These differences emanate from the type of wastewater they purify and the presence of varying plant species inside the $\mathrm{CW}$ columns (Scholz and $\mathrm{Xu}, 2002$; Hagendorf et al., 2005). Microbiological research using both classical and molecular approaches is required to fully understand microbial relationships inside such biocoenoses.

In this experiment, synthetic communal wastewater containing $5 \mathrm{mg} / \mathrm{l}$ sulfamethoxazole (SMX) was treated in a vertical flow lab-scale constructed wetland system, both with and without the plants. It is known that even small doses of bactericidal agents added to wastewater support the occurrence of resistant bacterial strains. Therefore in this experiment, both the identification of bacteria potentially resistant to SMX present in this CW system and the estimation of the SMX-resistance mechanism were attempted.

In this research, 14 bacterial strains resistant to SMX were isolated. Interestingly, all of these, on the basis of $16 \mathrm{~S}$ rRNA gene sequencing, were identified as 
Table 2. Biochemical characteristics of the SMX-resistant strains isolated in this study (biochemical tests results for the KK strains with the same genetic identification: isolates 4 and 14 - light gray; 3, 5, 7, 9, 10, 12, 13 - dark gray)

\begin{tabular}{|c|c|c|c|c|c|c|c|c|c|c|c|c|c|c|}
\hline \multirow{2}{*}{ Test } & \multicolumn{14}{|c|}{ Strain KK no. } \\
\hline & 1 & 2 & 3 & 4 & 5 & 6 & 7 & 8 & 9 & 10 & 11 & 12 & 13 & 14 \\
\hline$\beta$-galactosidase production & - & - & - & - & - & - & - & - & - & - & - & - & - & - \\
\hline Arginine dihydrolase production & + & + & + & + & + & - & - & + & - & + & - & + & + & + \\
\hline Lysine decarboxylase production & - & - & - & - & - & - & - & - & - & - & - & - & - & - \\
\hline Ornithine decarboxylase production & - & - & + & - & - & - & - & - & - & - & - & - & - & - \\
\hline Citrate utilization & - & + & + & + & + & + & + & - & - & - & - & - & - & - \\
\hline $\mathrm{H}_{2} \mathrm{~S}$ production & - & - & - & - & - & - & - & - & - & - & - & - & - & - \\
\hline Urease production & - & - & - & - & - & - & - & - & - & - & - & - & - & - \\
\hline Tryptophan deaminase production & - & - & - & - & - & - & - & - & - & - & - & - & - & - \\
\hline Indole production & - & - & - & - & - & - & - & - & - & - & - & - & - & - \\
\hline Acetoin production & + & + & + & + & + & + & + & - & - & - & - & - & - & - \\
\hline Gelatinase production & - & + & + & + & + & + & + & - & - & + & + & + & + & + \\
\hline Glucose fermentation/oxidation & - & + & - & - & - & - & - & - & - & - & - & - & - & - \\
\hline Mannitol fermentation/oxidation & - & - & - & - & - & - & - & - & - & - & - & - & - & - \\
\hline Inositol fermentation/oxidation & - & - & - & - & - & - & - & - & - & - & - & - & - & - \\
\hline Sorbitol fermentation/oxidation & - & - & - & - & - & - & - & - & - & - & - & - & - & - \\
\hline L-rhamnose fermentation/oxidation & - & - & - & - & - & - & - & - & - & - & - & - & - & - \\
\hline D-saccharose fermentation/oxidation & & + & - & + & - & - & - & - & - & - & - & - & - & - \\
\hline D-melibiose fermentation/oxidation & - & - & - & - & - & - & - & - & - & - & - & - & - & - \\
\hline Amygdaline fermentation/oxidation & + & + & + & + & - & - & + & - & + & - & + & + & + & - \\
\hline L-arabinose fermentation/oxidation & + & + & + & + & - & - & + & + & + & + & + & + & + & + \\
\hline Catalase production & + & + & - & + & + & + & + & - & + & - & + & + & + & + \\
\hline Oxidase production & - & - & - & - & - & - & - & - & - & - & - & - & - & - \\
\hline Hemolysis & + & - & - & + & + & - & + & - & - & - & - & + & + & + \\
\hline
\end{tabular}

Bacillus representatives. However, as stated by Maughan and Van der Auvera (2011), 16S rRNA gene sequences, although useful in phylogenetic studies at the genus level, have been questioned in the case of closely related species groups such as Bacillus where insufficient divergence in the $16 \mathrm{~S}$ rRNA molecule hinders the resolution of strains and species relationships. In 2004, the Bacillus genus was taxonomically divided into two separate groups: B. subtilis and B. cereus (Fritze, 2004). The Bacillus cereus group consists of: $B$. anthracis, $B$. cereus, $B$. mycoides, $B$. pseudomycoides $B$. thuringiensis and $B$. weihenstephanensis. The Bacillus subtilis group includes: B. subtilis spp. subtilis, $B$. subtilis spp. spizizenii, $B$. mojavensis, $B$. vallismortis, $B$. clausii, $B$. atrophaeus, $B$. amyloliquefaciens, B. licheniformis,
B. sonorensis, B. firmus, B. lentus and B. sporothermodurans. It is easy to distinguish the bacteria belonging to Bacillus cereus and $B$. subtilis groups from other Grampositive bacteria, but difficult to distinguish the members of one Bacillus genus. However, Pignatelli et al. (2009) stressed that, despite the fact that a molecular analysis based on other housekeeping genes is useful for single Bacillus isolates studied intensively in the laboratory, in the case of an environmental bacteria, 16S rRNA gene analysis still remains the gold standard in their identification. In this study, the 16S rRNA sequencing led to the identification of all the isolates as Bacillus. The identification of all SMX-resistant strains as Bacillus was surprising, especially when taking into consideration the fact that it is rather Gram-negative rods, such as 
Table 3. The most probable genetic identification of the SMX-resistant strains isolated in this study

\begin{tabular}{|c|c|c|c|c|}
\hline \begin{tabular}{c|} 
KK \\
strain \\
no.
\end{tabular} & Identification & $\begin{array}{l}\text { Query } \\
\text { cover }\end{array}$ & Identities & $\begin{array}{l}\text { NCBI selected } \\
\text { reference } \\
\text { sequence }\end{array}$ \\
\hline \multirow[b]{2}{*}{1} & Bacillus cereus strain CHA4 16S ribosomal RNA gene, partial sequence & $100 \%$ & $100 \%$ & KU886294.1 \\
\hline & $\begin{array}{l}\text { Bacillus thuringiensis strain TS124 16S ribosomal RNA gene, } \\
\text { partial sequence }\end{array}$ & $100 \%$ & $100 \%$ & KT851525.1 \\
\hline 2 & Bacillus cereus strain MSt-8 16S ribosomal RNA gene, partial sequence & $59 \%$ & $81 \%$ & KJ865589.1 \\
\hline 3 & Bacillus cereus $16 \mathrm{~S}$ ribosomal RNA gene & $100 \%$ & $100 \%$ & KT026101.1 \\
\hline 4 & Bacillus cereus strain MS-4 16S ribosomal RNA gene, partial sequence & $100 \%$ & $100 \%$ & KU296971.1 \\
\hline 5 & Bacillus cereus $16 \mathrm{~S}$ ribosomal RNA gene & $100 \%$ & $100 \%$ & KT026101.1 \\
\hline \multirow{2}{*}{6} & $\begin{array}{l}\text { Bacillus subtilis subsp. inaquosorum strain } \mathrm{Ph} \text { _04B6.2 16S ribosomal RNA } \\
\text { gene, partial sequence }\end{array}$ & $100 \%$ & $99 \%$ & KT719986.1 \\
\hline & $\begin{array}{l}\text { Bacillus methylotrophicus strain MER_166 16S ribosomal RNA gene, } \\
\text { partial sequence }\end{array}$ & $100 \%$ & $99 \%$ & KT719749.1 \\
\hline 7 & Bacillus cereus $16 \mathrm{~S}$ ribosomal RNA gene & $100 \%$ & $100 \%$ & KT026101.1 \\
\hline 8 & Bacillus sp. M6(2015) 16S ribosomal RNA gene, partial sequence & $100 \%$ & $99 \%$ & KR153957.1 \\
\hline 9 & Bacillus cereus $16 \mathrm{~S}$ ribosomal RNA gene & $100 \%$ & $100 \%$ & KT026101.1 \\
\hline 10 & Bacillus cereus $16 \mathrm{~S}$ ribosomal RNA gene & $100 \%$ & $100 \%$ & KT026101.1 \\
\hline \multirow[b]{2}{*}{11} & Bacillus sp. LW-22 16S ribosomal RNA gene, partial sequence & $100 \%$ & $100 \%$ & KR258770.1 \\
\hline & $\begin{array}{l}\text { Bacillus amyloliquefaciens strain } Z \text { Q1107 16S ribosomal RNA gene, } \\
\text { partial sequence }\end{array}$ & $100 \%$ & $100 \%$ & KJ538551.1 \\
\hline 12 & Bacillus cereus $16 \mathrm{~S}$ ribosomal RNA gene & $100 \%$ & $100 \%$ & KT026101.1 \\
\hline 13 & Bacillus cereus $16 \mathrm{~S}$ ribosomal RNA gene & $100 \%$ & $100 \%$ & KT026101.1 \\
\hline 14 & Bacillus cereus strain MS- 4 16S ribosomal RNA gene, partial sequence & $100 \%$ & $100 \%$ & KU296971.1 \\
\hline
\end{tabular}

Table 4. The presence of sul1, sul2 and sul3 genes in SMX-resistant strains isolated from the constructed wetlands

\begin{tabular}{|c|c|c|c|c|c|c|c|c|c|c|c|c|c|c|}
\hline \multirow{2}{*}{ Sul gene } & \multicolumn{14}{|c|}{ Strain KK no. } \\
\hline & 1 & 2 & 3 & 4 & 5 & 6 & 7 & 8 & 9 & 10 & 11 & 12 & 13 & 14 \\
\hline Sul1 & + & + & + & + & + & + & + & + & + & + & + & + & + & + \\
\hline Sul2 & + & - & - & - & - & - & - & - & - & - & + & + & + & - \\
\hline Sul3 & - & - & + & + & + & - & - & - & - & - & - & - & - & - \\
\hline
\end{tabular}

Escherichia coli, that should be isolated from wastewater treatment systems. Nonetheless, it had previously been stated that Bacillus species also present resistance toward SMX, as they may possess sul genes (Phuong Hoa et al., 2008; Luna et al., 2007; Wang et al., 2014). Similarly, other Gram-positive bacteria such as Arthrobacter (Phuong Hoa et al., 2008), Terrabacter, Dietzia or Agrococcus (Phuong Hoa et al., 2010) can also be resistant toward SMX as they too carry sulgenes.

Given the previous statements (Maughan and Van der Auvera, 2011; Pignatelli et al., 2009), the molecular identification in this paper was further supported by biochemical characterization aimed at presenting the diversity among SMX-resistant Bacillus strains isolated from CW. It should be underlined that in the case of KK4 and KK14 strains the molecular identification indicated the same $B$. cereus strain (accession No KU296971.1), despite the fact that the strains differed in their biochemical properties. Strain KK4 gave positive results for citrate utilization, acetoin production, D-saccharose and amygdaline fermentation, while KK14 gave negative results in those 4 tests. There was a similar situation in the case 


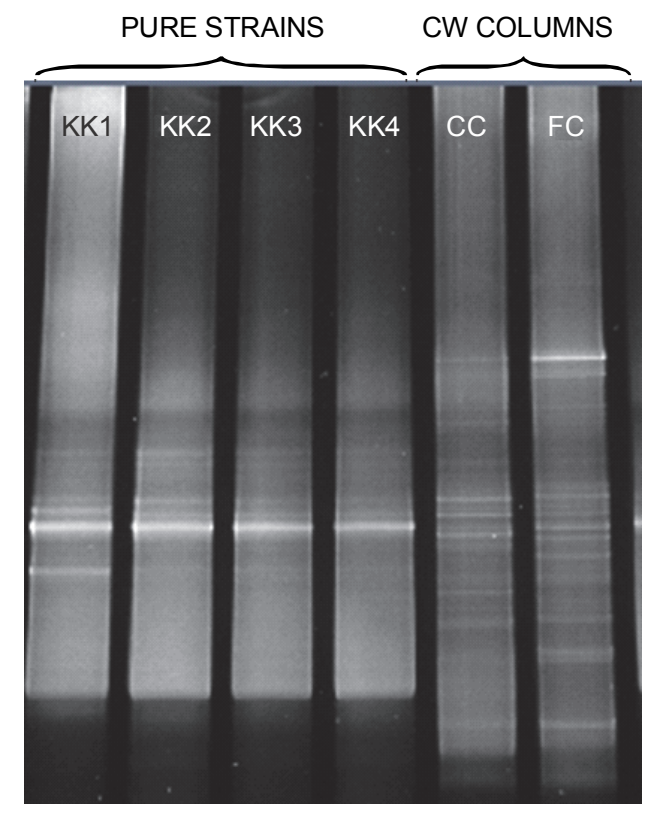

Fig. 2. Example of DGGE fingerprinting of $16 \mathrm{~S}$ rRNA partial gene PCR amplicons of KK1-4 SMX-resistant strains and constructed wetland bacterial community samples from the control column (CC) and that fed with SMX-rich wastewater (FC)

of KK3, KK5, KK7, KK9, KK10, KK12 and KK13 strains that were genetically identified as $B$. cereus (accession no. KT026101.1). These strains gave different results for the production of arginine dihydrolase, ornithine decarboxylase, gelatinase, and catalase, and also citrate utilization, amygdaline fermentation/oxidation and hemolysis. These results show that the proper description of bacterial strains possessing particular properties which are of interest to researchers requires further study and such a description should be characterized biochemically in order to present the diversity of the environmental strains belonging to one species.

The bacteria that belong to Bacillus genus are commonly found in the environment, but only two are regarded as medically significant: $B$. anthracis, which causes anthrax; and $B$. cereus, responsible for a food-borne illness similar to that caused by the Staphylococcus species (Koneman et al., 1997). Bacteria producing some types of toxins can cause $\beta$-hemolysis, which is an adaptation to certain pathogenic bacteria occurring during an infection. Most, but not all bacteria producing hemolysin can be pathogenic. For example, among hemolytic representatives of the Listeriagenus (possessing the hly gene encoding hemolysin), L. monocytogenes, L. ivanovii and L. seeligeri, only two are pathogenic: $L$. monocytogenes for humans and animals; and L. ivanovii for animals (Muskalska and Szymczak, 2015). In the case of the Bacillus isolates presented in this study, seven out of the 14 strains were hemolytic. They were all identified as Bacillus cereus (in the case of $\mathrm{KK} 1$, there was also a possibility that it was $B$. thuringensis, belonging to the $B$. cereus group). According to the description given by the UK Standards for Microbiology Investigations (2015), only B. anthracis is non-hemolytic or weakly hemolytic. In the case of SMX-resistant strains, nonhemolytic strains were also identified as $B$. cereus or $B$. subtilis. As these isolates were environmental strains, these results confirm the earlier results of Klee and coworkers (2006), who stated that a large number of environmental Bacillus strains not belonging to $B$. anthracis species are non-hemolytical.

All 14 isolates identified in this study presented SMX resistance toward sulfamethoxazole at the concentration of $5 \mathrm{mg} / \mathrm{l}$. According to previous studies, many isolates of the Bacillus genus are resistant to SMX (Luna et al., 2007). The mechanism of SMX resistance has mostly been studied in Gram-negative bacteria from the Enterobacteriaceae family, mainly in medically relevant E. coli (Kerrn et al., 2002). These bacteria possess three genes for SMX resistance: sul1, sul2 and sul3, but they appear in bacterial isolates only in the case of a high (above $500 \mathrm{mg} / \mathrm{l}$ ) MIC (minimal inhibitory concentration) value (Hammerum et al., 2006). These bacteria are also ubiquitous in WWTP systems. Among the isolates analyzed in this study, all 14 strains possessed the sul1 gene, but only 4 and 3 of them gave a positive result in sul2 and sul3 PCR tests, respectively. None of the isolated strains possessed all three sulgenes. Such a situation could be linked to the level of SMX-resistance expressed as the MIC value. In the case of $E$. coli, the MIC value for SMX-resistance is in the range between 64 and $1024 \mathrm{mg} / \mathrm{l}$ and, in the case of such a range of SMX concentration, $15 \%$ of $E$. coli isolates possessed more than one sulfonamide-resistance gene (Hammerum et al., 2006). In this study, the concentration of sulfamethoxazole in wastewater was relatively low $(5 \mathrm{mg} / \mathrm{l})$; therefore, it could be suspected that the isolated bacterial strains were susceptible to SMX at higher concentrations. Nevertheless, in this technological $\mathrm{CW}$ system those bacteria surviving the $5 \mathrm{mg} / 1$ concentration of SMX could be relevant players in the bacterial community dealing with the biological removal of SMX. 
It cannot excluded that the presence of one or more sul genes in these bacteria could also be the result of horizontal gene transfer.

To assess the location of the SMX-resistant bacteria isolate genotypes in the total bacterial community of the CW system, PCR-DGGE analysis was performed. On the basis of the results obtained, it could be stated that SMX-resistant bacteria were not dominant in the total bacterial community in $\mathrm{CW}$ columns, irrespective of whether SMX implementation occurred or not to the wastewater treated in the system. The isolated strains possessed more than one type of partial 16S rRNA gene genotype, which was caused by the presence of several ribosomal operons ( $r r n)$; and therefore, it was impossible to identify only one SMX-resistant genotype in the total bacterial community of the constructed wetland columns. Additionally, the SMX-resistant genotypes (as a single DNA band in the DGGE fingerprint line) present at the same level as the DNA band in the total community fingerprint were very weak and difficult to distinguish. This made their identification by sequencing impossible (Fig. 2). This result is confirmed by Lerner and coworkers (2006), who stressed that the results of DGGE analyzes should be examined very carefully, because there is a strong bias for dominant genotypes and multiple rrn operon copies from the same bacteria which yield various bands. These results show that PCRDGGE is a very sensitive method and this feature is both advantageous and disadvantageous in the analysis of bacterial communities. It is possible to present one-point difference in the genotype sequence, but at the same time some isolates can be represented by more than one DNA band in the fingerprint. Thus, the community structure may not necessarily reflect the real diversity of the community, due to the possibility of several $16 \mathrm{~S}$ rRNA gene genotypes originating from one bacterial strain.

\section{Conclusions}

On the basis of our studies several conclusions can be drawn:

- SMX-resistant bacteria isolated from the CW system belong to the Gram-positive Bacillus genus;

- despite belonging to one genus, all 14 isolates differed in their biochemical profile. Some strains identified as belonging to one species differ in their biochemical properties. These results point to the wide diversity of the biochemical features presented by the environmental bacterial isolates;

- all 14 isolates possess at least one sul gene known to be a genetic element responsible for SMX resistance; none of the isolates presented all three sul genes;

- according to the results obtained with PCR-DGGE, none of the SMX-resistant isolates is a dominant genotype in the $\mathrm{CW}$ system community.

\section{Acknowledgements}

This study was financially supported by the Faculty of Power and Environmental Engineering of the Silesian University of Technology (grant No 80/080BKM15/0028) and The National Science Center Poland (grant No UMO2012/05/B/ST8/ 02739). The authors are grateful to Monika Nowrotek for technological system supervision.

\section{References}

Fritze D. (2004) Taxonomy of the genus Bacillus and related genera: the aerobic endospore-forming bacteria. Phytopathology 94: 1245-1248.

Hagendorf U., Diehl K., Feuerpfeil I., Hummel A., Szewzyk R. (2005) Microbiological investigations for sanitary assessment of wastewater treated in constructed wetlands, Wat. Res. 39: 4849-4858.

Hammerum A.M., Sandvang D., Andersen S.R., Seyfarth A.M., Porsbo L.J., Frimodt-Møller N., Heuer O.E. (2006) Detection of sul1, sul2 and sul3 in sulphonamide resistant Escherichia coli isolates obtained from healthy humans, pork and pigs in Denmark. Int. J. Food Microbiol. 106: 235-237.

Kerrn M.B., Klemmens T., Frimodt-Møller N., Espersen F. (2002) Susceptibility of Danish Escherichia coli strains isolated from urinary tract infections and bacteraemia, and distribution of sul genes conferring sulphonamide resistance. J. Antimicrob. Chemother. 50: 513-516.

Klee S.R., Nattermann S., Becker M., Urban-Schriefer T., Franz D., Appel B. (2006) Evaluation of different methods to discriminate Bacillus anthracis from other bacteria of the Bacillus cereus group. J. Appl. Microbiol. 100: 673681.

Koneman E.W., Allen S.D., Janda W.M., Schreckenberger P.C., Winn W.J. (ed). (1997) Color Atlas and Textbook of Diagnostic Microbiology. $5^{\text {th }}$ ed. Philadelphia: Lippincott Williams and Wilkins.

Lerner A., Shor Y., Vinokurov A., Okon Y., Jurkevitch E. (2006) Can denaturing gradient gel electrophoresis (DGGE) analysis of amplified 16S rDNA of soil bacterial populations be used in forensic investigations? Soil Biol. Biochem. 38: 1188-1192.

Luna V.A., King D.S., Gulledge J., Cannons A.C., Amuso P.T., Cattani J. (2007) Susceptibility of Bacillus anthracis, Bacillus cereus, Bacillus mycoides, Bacillus pseudomycoides and Bacillus thuringiensis to 24 antimicrobials using 
Sensititre $^{\circledR}$ automated microbroth dilution and Etest ${ }^{\circledR}$ agar gradient diffusion methods. J. Antimicrob. Chemother. 60: 555-567.

Łuczkiewicz A., Felis E., Ziembinska A., Gnida A., Kotlarska E., Olańczuk-Neyman K., Surmacz-Górska J. (2013) Resistance of Escherichia coli and Enterococcus spp. to selected antimicrobial agents present in municipal wastewater. J. Water Health. 11: 600-12

Martinez J.L. (2009) Environmental pollution by antibiotics and by antibiotic resistance determinants. Environ. Pollut. 157: 2893-2902.

Maughan H., Van der Auwera G. (2011) Bacillus taxonomy in the genomic era finds phenotypes to be essential though often misleading. Infect. Genet. Evol. 11: 789-797.

Muskalska K.B., Szymczak B. (2015) Postępy badań nad bakteriami z rodzaju Listeria (in Polish). Post. Mikrobiol. 54: 123-132.

Muyzer G., De Waal E., Uitierlinden A.G. (1993) Profiling of complex microbial populations by denaturing gradient gel electrophoresis analysis of polymerase chain reactionamplified genes coding for $16 S$ rRNA. Appl. Environ. Microbiol. 59: 695-700.

Nõlvak H., Truu M., Tiirik K., Oopkaup K., Sildvee T., Kaasik A., Mander Ü., Truu J. (2013) Dynamics of antibiotic resistance genes and their relationships with system treatment efficiency in a horizontal subsurface flow constructed wetland. Sci. Total Environ. 461-462: 636-644.

Perreten V., Boerlin P. (2003) A new sulfonamide resistance gene (sul3) in Escherichia coli is widespread in the pig population of Switzerland. Antimicrob. Agents Chemother. 47: 1169-1172.

Phuong Hoa P.T., Nonaka L., Hung Viet P., Suzuki S. (2008) Detection of the sul1, sul2, and sul3 genes in sulfonamideresistant bacteria from wastewater and shrimp ponds of north Vietnam. Sci. Total Environ. 405: 377-384.

Pignatelli M, Moya A, Tamames J. (2009) EnvDB, a database for describing the environmental distribution of prokaryotic taxa. Environ. Microbiol. Rep. 1: 191-197.
Scholz M., Xu J. (2002) Performance comparison of experimental constructed wetlands with different filter media and macrophytes treating industrial wastewater contaminated with lead and copper. Bioresour. Technol. 83: 7179.

Suzuki S., Ogo M., Koike T., Takada H., Newman B. (2015) Sulfonamide and tetracycline resistance genes in totaland culturable-bacterial assemblages in South African aquatic environments. Front Microbiol. 6: 796.

Suzuki S., Ogo M., Miller T.W., Shimizu A., Takada H., Siringa M.A.T. (2013) Who possesses drug resistance genes in the aquatic environment?: sulfamethoxazole (SMX) resistance genes among the bacterial community in water environment of Metro-Manila, Philippines. Front. Microbiol. 4: 102.

UK Standards for Microbiology Investigations Identification of Bacillus species, Public Health England (2015) Issued by the Standards Unit, Microbiology Services, PHE Bacterio$\log y$ - Identification. ID 9. 3: 1-27.

Vymazal J. (2005) Horizontal sub-surface flow and hybrid constructed wetlands systems for wastewater treatment. Ecol. Eng. 25: 478-490.

Wang N., Yang X., Jiao S., Zhang J., Ye B., Gao S. (2014) Sulfonamide-Resistant Bacteria and Their Resistance Genes in Soils Fertilized with Manures from Jiangsu Province, Southeastern China. PLoS One 9: e112626.

Xu J., Xu Y., Wang H., Guo C., Qiu H., He Y., Zhang Y., Li X., Meng W. (2015) Occurrence of antibiotics and antibiotic resistance genes in a sewage treatment plant and its effluent-receiving river. Chemosphere 119: 1379-1385.

Ziembińska-Buczyńska A., Drzewicki A., Kulikowska D. (2015) Impact of flowback water on activated sludge biocenosis during municipal wastewater treatment. Ecol. Chem. Eng. 22: 611-624. 